\title{
A Palynological Zonation for the Paleocene of the North Sea Basin
}

\author{
THEO SCHRÖDER \\ Shell U.K. Exploration \& Production \\ Shell-Mex House, \\ London WC2R ODX
}

\begin{abstract}
The proprietary palynological zonation developed by Shell U.K. Exploration and Production for the Paleocene of the North Sea Basin is formally released and described. Four main zones - in ascending order PT11, PT13, PT15 and PT19 - can be consistently recognised basin-wide from microplankton assemblages. The zonation for the central North Sea provides a further fourfold, mainly pollen-based, subdivision PT19.1, PT19.2, PT19.3 and PT19.4 - of the prospective Forties Formation. Changes in climate may be considered a major influence over quantitative shifts in the Late Paleocene pollen spectrum and so it is reasonable to assume that such shifts may represent 'time-lines'; hence the subzones may be valid over a much wider area than the central North Sea. J. Micropalaeontol, 11 (2): 113-126, December 1992.
\end{abstract}

\section{INTRODUCTION}

Biostratigraphers in Shell U.K. E \& P have been working with the Tertiary of the North Sea since the mid 1960's when attempts at subdivision were initially made by means of foraminifera and marine microplankton. The use of combined, jointly defined biozones - known as PT zones (standing for Palynology / Palaeontology in the Tertiary) - dates back to that early period. However, palynological investigations soon concentrated on those intervals deposited under restricted marine conditions unfavourable for foraminifera, radiolaria, diatoms, ostracods and calcareous nannoplankton. As a result, the floras from zones PT11, PT13 and PT15 received only superficial attention since the use of foraminifera and calcareous nannoplankton provided satisfactory stratigraphic control. In contrast, zone PT19 was extensively studied by palynologists to establish a chronostratigraphic framework for the prospective Forties Formation. The inclusion of pollen as marker taxa in the scheme dates back to the late 1960 's after it had become clear that an adequate framework could not be realized on microplankton alone.

Initially reserved for future refinement of the PT scheme, the intermediate numbers $12,14,16,17$ and 18 were actually never used.

The selection of time-significant pollen marker taxa for the Late Paleocene was based on data derived from north-west continental Europe, in particular central and northern Germany (Krutzsch, 1962, 1966, 1967, 1968) combined with Shell's evaluation of central North Sea wells. Since Krutzsch (op. cit.) concentrated almost solely on sporomorph taxa, the ranges of selected microplankton indices were established in-house. Due to operational constraints, only the initially selected marker types were consistently logged during the past twenty years, as a result of which no detailed record of the accompanying flora is available. The latter, being usually rich and diverse, offers potential for further stratigraphic resolution.
The palaeoenvironment of deposition for the German 'type' area and the central North Sea are completely dissimilar. The former has a predominantly deltaic (occasionally even lacustrine) to shallow marine setting (Ziegler, 1990) whilst in the latter area it ranges from slope deposits to deep marine basinal sequences with submarine fan deposits sourced from the northwest (Kulpecz \& van Geuns, 1990). Despite this contrast, the pollen and spore floras appear similar in both taxa and quantitative composition as a result of common vegetational parentage and of drainage into the same near-enclosed marine basin in which there was good mixing prior to deposition and burial.

The range chart (Fig. 1) illustrates the features salient to zonal and subzonal diagnosis. The palynological fourfold subdivision of the PT19 zone and the recognition of the underlying PT15, PT13 and PT11 zones hinges on nine key taxa. The additional taxa on the range chart serve to permit 'fine tuning' and for comparative purposes the micropalaeontological criteria that define the PT zonal scheme are also incorporated.

\section{SAMPLE PREPARATION}

Palynological sample preparation procedures are well established and need no further elaboration here. However, a word of caution is due on the use of industrial gauzes for sieving. Gauzes not coarser than 10 micron are required to retain the bulk of palynomorphs, particularly the small pollen from the Late Paleocene which are used to establish the PT19 subzones. It is essential tocarry out frequent quality checks on the gauzes as considerable inconsistencies exist in mesh sizes of both the nominal 10 micron and 15 micron gauzes between different factory supplied batches. For example, the officially quoted 10 micron mesh size may be more than 20 micron. The wrong mesh size leads to a partial loss of flora and a gross distortion of the assemblage. 


\section{GENUS AND SPECIES LISTING}

Genera and species referred to in the text and on the range chart are listed below in alphabetical order, including an informal description of the morphological features that define useful variants of three published taxa.

\section{Dinophyceae}

(The taxonomic assignments of dinoflagellate cysts used are after Lentin \& Williams, 1989).

\section{Alisocysta margarita (Harland) Harland, 1979}

Alisocysta cf. margarita (Pl. 2, figs 1, 2)

Wall thick. Penitabular septa consistently low.

Distribution of intratabular sculptural elements much sparser than in A. margarita s.s, generally not more than two or three well separated microreticulate spongy elements per plate. This type effectively forms a transition between $A$. margarita s.s. and the smooth intratabular surfaces of $A$. circumtabulata (Drugg) Stover \& Evitt, 1978.

A. sp.1 in Heilmann-Clausen (1985) differs in showing a coarser reticulum which covers the plates entirely and in having high septa. Although thin-walled, specimens of $A . \mathrm{sp} .2$ (op. cit.) with low septa may include our variant.

Alisocysta reticulata Damassa, 1979

Alisocysta spp.

Apectodinium augustum (Harland) Lentin \& Williams, 1981

Apectodinium paniculatum (Costa \& Downie) Lentin \& Williams, 1977

Apectodinium spp.

Areoligera cf. senonensis (Pl. 1, figs 1-3)

Processes stout, erect and distally expanded. Processes of one and the same complex only rarely develop interconnecting 'bridges'; bridging then occurs approximately halfway along the processes, not distally. Large and distinct complexes may, or may not, be developed on dorsal side only; variant otherwise identical with $A$. senonensis Lejeune-Carpentier, 1938.

$A$. cf. senonensis in Heilmann-Clausen (1985) includes a specimen (Pl. 14, fig. 5) that appears similar as far as the nature and relative length of processes is concerned.

Areoligera spp.

Eisenackia crassitabulata Deflandre \& Cookson, 1955; emend. McLean, 1973

?Fromea laevigata (Drugg) Stover \& Evitt, 1978

Palaeoperidinium pyrophorum (Ehrenberg) Sarjeant, 1967

Palynodinium grallator Gocht, 1970

Spiniferites spp.

Spongodinium delitiense (Ehrenberg) Deflandre, 1936; emend.

Lucas-Clark, 1987

Subtilidinium minutum Morgenroth, 1968

\section{Chlorophyceae}

Pediastrum spp.

Prasinophyceae
Pollen

Alnipollentites verus (Potonié) Potonié, 1934

Bombacacidites reticulatus Krutzsch, 1961

Caryapollenites spp.

Caryapollenites cf. veripites (Pl. 2, figs 3,4 )

Without exception, all three pores are restricted to one hemisphere. All exopores standing back from the body's periphery by at least one exopore's width (sensu Nichols \& Ott, 1978, Plate 2, fig. 13).

Compositoipollenites rhizophorus - group

Included are C. rhizophorus subsp. rhizophorus (Potoniè), Potonié, 1960 and C. rhizophorus subsp. geiseltalensis (Pflug) Potonié, 1960.

Inaperturopollenites hiatus (Potonié) Thomson \& Pflug, 1953

Interpollis spp.

Labrapollis labraferoides (Krutzsch) Krutzsch, 1968

Oculopollis spp.

Platycaryapollenites spp.

Plicapollis pseudoexcelsus (Krutzsch) Krutzsch, 1961

Sequoiapollenites spp.

Tiliaepollenites microreticulatus - group

Included are T. microreticulatus Mai, 1961

and T. pseudoinstructus Mai, 1961

Tiliaepollenites spp.

Trudopollis spp.

\section{PALYNOLOGICAL DEFINITIONS OF THE PALEOCENE PT ZONES AND SUBZONES}

The main microfloral characteristics of the PT zones and subzones are discussed below in ascending order. The abbreviation FAT denotes the First Appearance in Time (or base occurrence) of a taxon. LAT denotes the Last Appearance in Time (or top occurrence). Reference is also made to both the dominant palynofacies (which, given local influences, is not necessarily restricted to a particular zone or subzone) and, where possible, the interpreted climate. The terminology used here to describe the palynofacies constituents is after Whitaker (1984) and van der Zwan (1990).

\section{Zone PT11}

The lower limit is drawn immediately above the LAT of Palynodinium grallator (defining top Maastrichtian).

The upper limit is taken at the LAT of Spongodinium delitiense. Comments. A detailed analysis of floras is not routinely carried out.

\section{Zone PT13}

The lower limit is drawn immediately above the LAT of Spongodinium delitiense (defining top PT11).

The upper limit is taken at the LAT of Alisocysta reticulata. Comments. A detailed analysis of floras is not routinely carried out. 
Paleocene Palynological Zonation

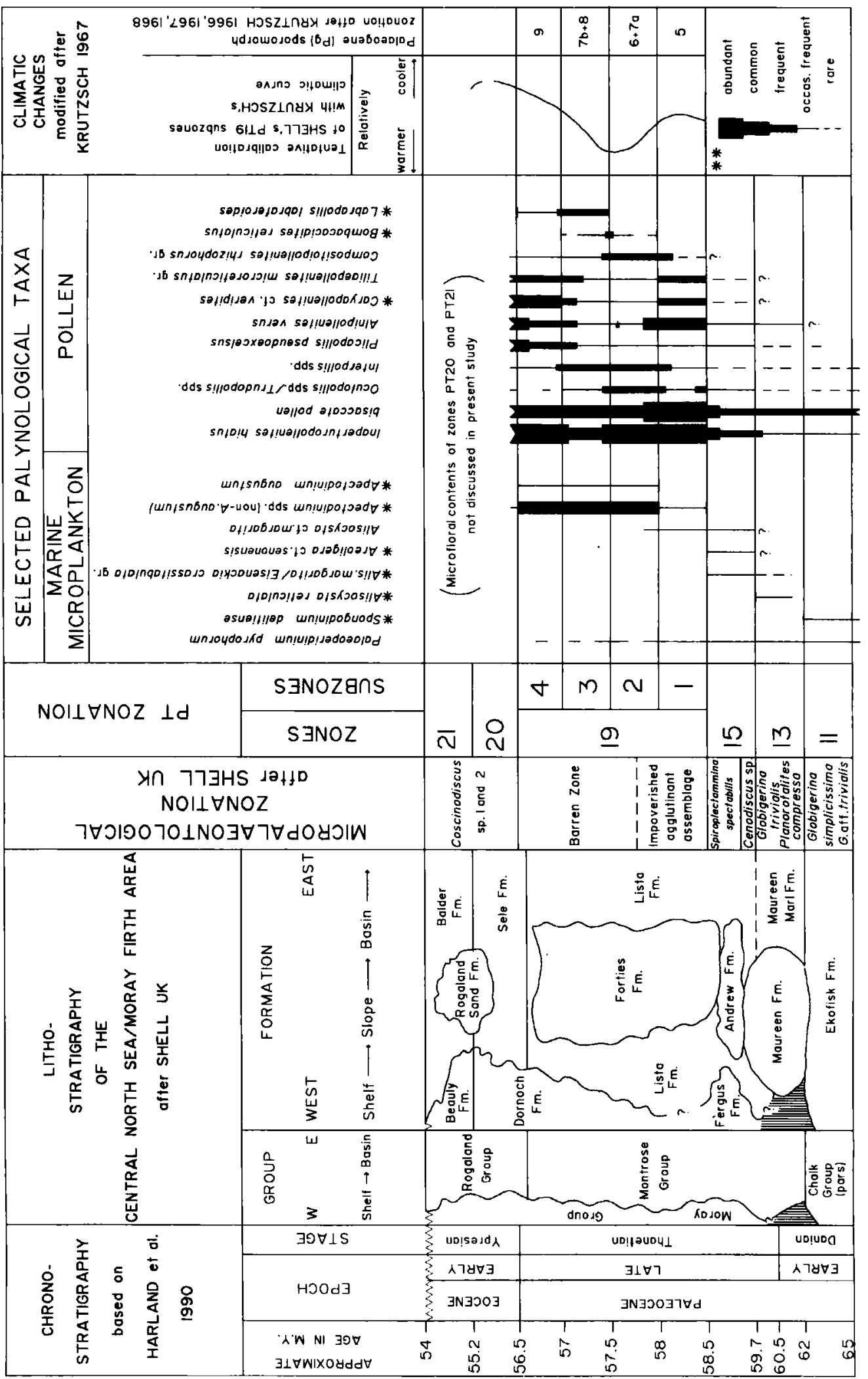



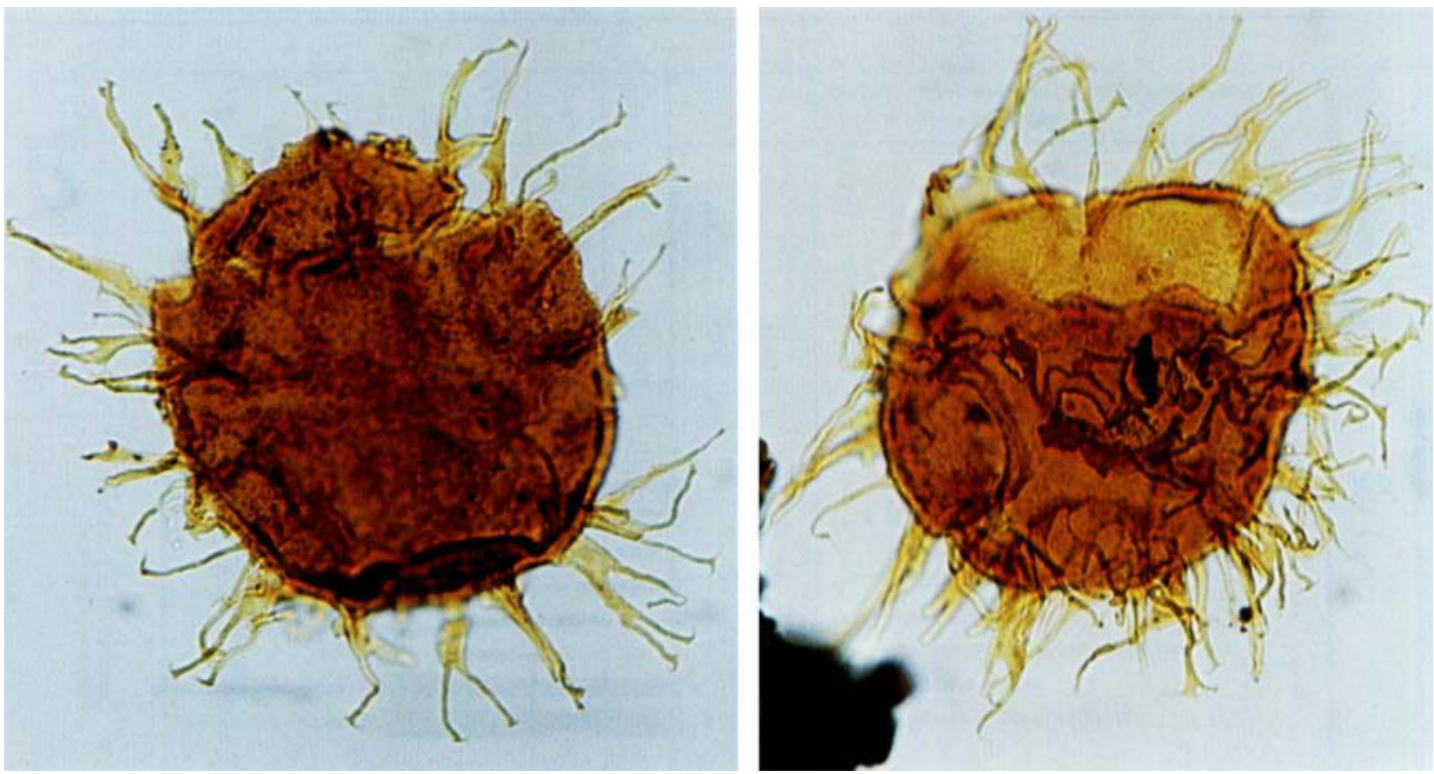

1

2

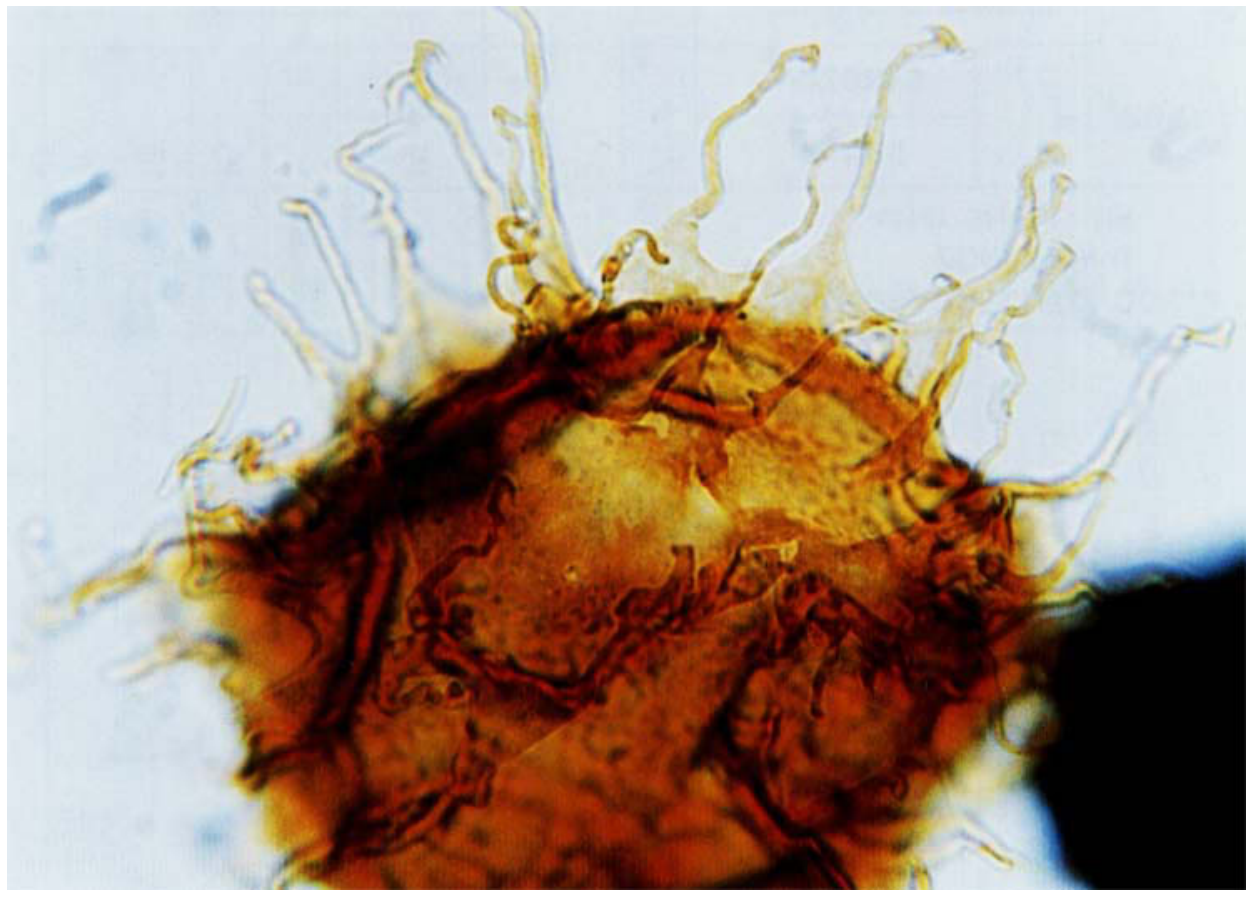

Figs. 1-3. Areoligera cf. senonensis Lejeune-Carpentier. Figs. 1, 2: x600, overall size 117 microns (fig.1) and $111 \mathrm{microns}$ (fig. 2); well Shell/Esso 22/ 6-1, 7473.5'. Fig. 3: closeup, x 1150, overall size 94 microns; well Shell/Esso 22/6-1, 7484'. 

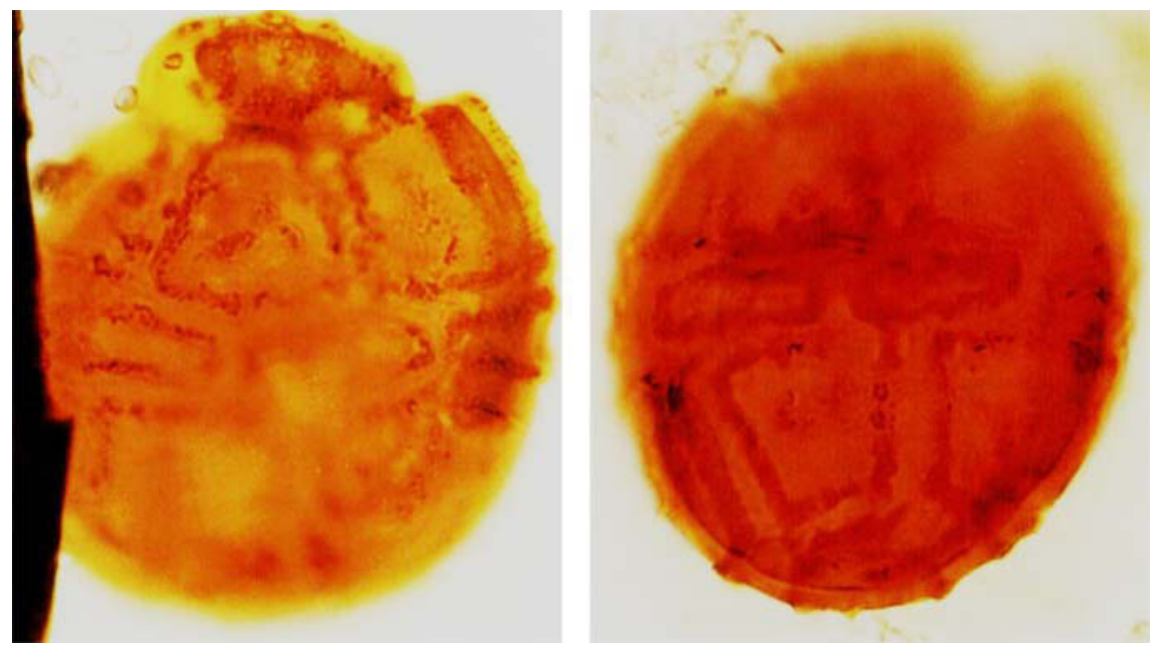

1

2
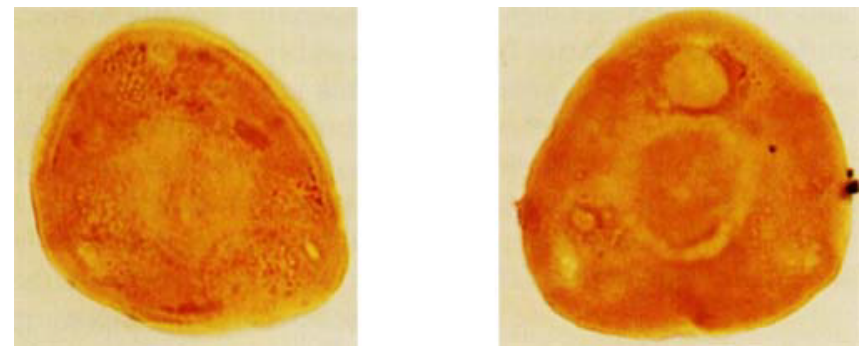

3

4

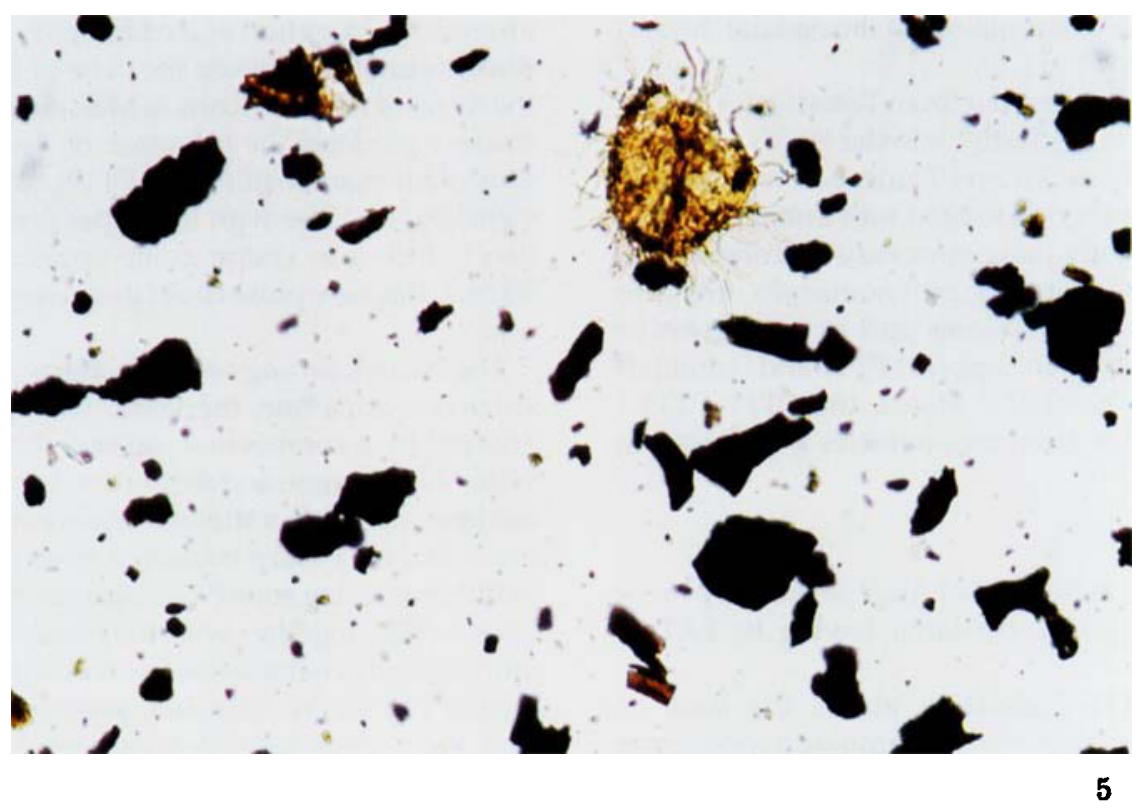

Explanation of Plate 2

Figs. 1, 2. Alisocysta cf. margarita (Harland) Harland. x 1300, length 52 microns (fig. 1) and 49 microns (fig. 2); well Shell/Esso 21/30-9A, 6730.1'. Figs. 3, 4. Caryapollenites cf. veripites Nichols and Ott. x 1200, size 28 microns (fig. 1) and 32 microns (fig 2); well Shell/Esso 22/6-1, 7180.5'.

Fig. 5. Palynofacies image of PT15. Palynomacerals 1 and 4 tend to predominate over other constituents, including palynomorphs. Coarse fraction slide (particles 30 microns and over), x 300, area shown approx. $420 \times 285$ microns; well Shell/Esso 22/6-1, 7473.5'. 


\section{Zone PT15}

The lower limit is drawn immediately above the LAT of Alisocysta reticulata (defining top PT13).

The upper limit is taken at the LAT of the Alisocysta margarita/ Eisenackia crassitabulata group and of Areoligera cf. senonensis. Both Alisocysta spp. and Areoligera spp. are tentatively given a quantitative top at this level. Also potentially diagnostic are the LAT of Subtilidinium minutum and ?Fromea laevigata.

Note that PT15 marker species are often encountered reworked into the overlying PT19 zone, posing a particular operational problem in cutting samples in which older age indicators are given priority over, presumed caved, younger floras. The issue around the PT15/PT19 boundary cannot be satisfactorily resolved unless sidewall samples or cores are available; the presence of Apectodinium spp. would then preclude an age older than PT19. However, in view of its patchy distribution throughout PT19.1, the absence of Apectodinium spp. in one or two samples should not necessarily be taken as conclusive evidence for PT15.

Palaeoperidinium pyrophorum and the genera Spiniferites, Alisocysta and Areoligera are often dominant. The latter two, probably for palaeoecological reasons, are rarely both present in significant numbers in the same assemblage. The reasons are still speculative but may include, for example, variations in water chemistry and turbulence. Pollen are occasionally abundant e.g. Inaperturopollenites hiatus, bisaccate pollen and triporate pollen, especially in the upper sequences of this zone.

Palynofacies: An oxygenated open marine setting prevails with microplankton usually predominant over sporomorphs. Terrestrial plant debris consists mainly of the opaque 'humic' palynomaceral type 4 (Pl. 2. fig. 5).

Pulsations in the uplift of the northern British Isles, which are responsible for shedding clastics into the North Sea Basin during the Paleocene - Early Eocene Thulean volcanic phase (e.g. Ziegler, 1990), probably dislodged vast amounts of terrestrial plant debris (mainly palynomacerals 1, 2 and 4). Reworked Jurassic and Cretaceous palynomorphs are also present. These organic influxes seem part of a progressive process, starting somewhere in (upper?) PT15 and culminating in PT19.1 and lower PT19.2. Hence the PT15/PT19.1 boundary is undetectable from palynofacies if a complete sequence is preserved.

\section{Subzone PT19.1}

The lower limit is drawn at the FAT of Apectodinium spp. with the exception of $A$. augustum, the latter having its FAT in subzone PT19.2.

The presence of PT15 indicators above the base of Apectodinium spp. in cores and sidewall samples is considered to be the result of reworking.

The upper limit is taken immediately below the FAT of $A$. augustum and/or the FAT of Bombacacidites reticulatus.

Inaperturopollenites hiatus and triporate pollen are numerically rich, bisaccate pollen is abundant. The 'relatively cool and/or wet' indices, particularly Alnipollenites verus, Sequoiapollenites spp., Caryapollenites spp. and Tiliaepollenites spp. are conspicuous. The rich pollen assemblages have potential for further stratigraphic subdivision; the quantitative bases of three 'relatively warm' indices, Interpollis spp., Oculopollis spp./Trudopollis spp. and, to a lesser extent (because of its erratic palaeogeographic distribution), Compositoipollenites rhizophorus, are proving meaningful in the upper part of the subzone.

Palaeoperidinium pyrophorum, Apectodinium spp. (including A. paniculatum) and the fresh water alga Pediastrum are all occasionally common.

Alisocysta cf. margarita is consistently present, albeit in low numbers.

Palynofacies: The transition from PT15 to PT19.1 marks a major event throughout the North Sea area, heralding the onset of restricted marine conditions, the first signs of which were apparent in the upper part of zone PT15 and prevailed into the basal Eocene zone PT21.

Particularly noteworthy is a considerable further increase in terrigenous input - including vast amounts of plant debris, especially opaque humic debris (palynomacerals 1 and 4) possibly indicating high river discharges (Plate 3: figure 1). This may have resulted from relatively cooler and wetter climatic conditions for the greater part of the subzone as suggested by the composition of the pollen assemblages. This cooling could have been caused by atmospheric volcanic ash following a particular violent or prolonged burst of pyroclastic activity associated with the opening of the Atlantic Ocean and the Shetland-Grampian uplift.

According to R.W. O'B. Knox (pers. comm.), a recently observed pyroclastic pulse is believed to occur somewhere around the inception of Apectodinium spp. This new pulse is thus postulated between the close of Pyroclastic Phase 1 and the onset of Phase 2 (Knox \& Morton, 1988). Since the close of Phase 1 predates the inception of Apectodinium spp. (and is thus older than Shell's zone PT19), and the onset of Phase 2 virtually coincides with the upper limit of the Forties Formation (which is as young as the upper part of Shell's subzone PT19.4) this new pulse could provide support for this hypothesis.

The basin's setting was effectively transformed into a restricted marine one, the water chemistry of which became affected by a combination of lowered salinity, lowered $\mathrm{pH}$, water stratification and dysaerobic bottom conditions. Faunal evidence indicates a stressed environment: the base of PT19.1 is marked by a sharp transition from the rich, diverse faunas of the underlying zone PT15 into brown, oligospecific associations which, together with the diatom Coscinodiscus (C. sp.4 and 13, Shell), characterize both subzone PT19.1 and the lower part of PT19.2 (W. Sikkema, pers. comm.). Blooming of the diatoms is attributed to nutrient enrichment of surface waters resulting from increased river discharges (H.A. Jonkers, pers. comm.).

The recognition of a subsequent gradual shift back to a relatively warmer climate, starting in uppermost PT19.1 and lasting until upper PT19.3, is based on a sudden increase of pollen from thermophilic plants. This warmer phase may well reflect a relative lull in pyroclastic activity in the Thulean Province. 
Sporomorphs are usually diverse, very rich to abundant and predominate over the non-diverse microplankton.

\section{Subzone PT19.2}

The lower limit is primarily taken at the FAT of Apectodinium augustum but also at the FAT of Bombacacidites reticulatus, although the latter tends to be rare towards its base.

The upper limit is taken immediately below the FAT of Labrapollis labraferoides (defining base PT19.3).

The approximate position of the PT19.2/PT19.3 boundary can often be narrowed down by the presence of a very short-lived quantitative peak of B. reticulatus.

Common occurrences of both Palaeoperidinium pyrophorum and Pediastrum, an abundance of bisaccate pollen and the presence of occasionally common Alnipollenites verus all persist from PT19.1 into the lower part of PT19.2.

Alisocysta cf. margarita has its top in lower PT19.2. High counts of Inaperturopollenites hiatus and common occurrences of Interpollis spp. are present throughout. The quantitative base of Platycaryapollenites spp. is located somewhere in the lower to middle part of the subzone.

Palynofacies: The restricted marine conditions continued. Abundant influxes of terrestrial plant debris are typical, as in PT19.1, except for a marked drop in the amount of the opaque 'humic' palynomacerals 1 and 4 as from the middle of PT19.2 (Pl. 3, fig. 2). This may suggest either a changing distance to source or a change of the source. The sediment-water interface became progressively more anaerobic, culminating in the preservation of sapropelic matter - here called SOM (Structureless Organic Matter) - which is occasionally abundant in the upper part of the subzone together with an upward increase in palynomacerals 2 and 3 .

The climate continued to recover to become relatively warm and / or dry, possibly reaching a maximum around the PT19.2/ PT19.3 boundary. The comparatively non-diverse microplankton assemblage is rich in numbers. Sporomorphs continue to be fairly abundant and diverse.

The middle of this subzone marks the top of diatoms and oligospecific faunas that first appeared in PT19.1, until diatoms reappear in the Early Eocene zone PT20.

\section{Subzone PT19.3}

The lower limit is taken at the FAT of Labrapollis labraferoides. Roughly coinciding with this event is a brief quantitative increase of Bombacacidites reticulatus.

The upper limit is taken at the LAT of $B$. reticulatus. Since the species is known to be rare towards the top of its range, the poor presence of Caryapollenites cf. veripites in PT19.3 can often be used as an additional criterion. However, in a complete or expanded development of the PT19.3/PT19.4 boundary C. cf. veripites can be expected to display a minor quantitative increase in upper PT19.3, below its clear quantitative base that marks the lower limit of PT19.4. The subzonal boundary is then drawn at the point at which the total number of specimens of L. labraferoides and Interpollis spp. combined (defining PT19.3) exceeds the total number of specimens of $C$. cf. veripites (defining PT19.4).

Inaperturopollenites hiatus is numerically not as rich as in adjacent subzones, particularly not in the middle of PT19.3. Characteristic for the subzone are common occurrences of $L$. labraferoides and Interpollis spp; the former displaying a peak towards both the lower and upper limit of the subzone. In the upper part Alnipollenites verus, Caryapollenites spp. and Tiliaepollenites spp. become common. Platycaryapollenites spp are less common in the middle of this subzone.

Palynofacies: Restricted marine conditions persist with substantial influxes of terrestrial plant debris with palynomacerals 2 and 3 predominant (Pl. 4: fig. 1).

A further increase in the content of SOM indicates a strongly reducing environment with fully anaerobic bottom conditions in the deeper parts of the basin. Such widespread stagnation is typical of a well stratified water mass which may be due to salinity and/or thermal differences. Impeded water circulation in the North Sea Basin during the Late Paleocene resulted from the basin's isolation (Ziegler, 1990); the only communication was with the Norwegian-Greenland Sea.

The climate in the lower part of the subzone is basically the same as in upper PT19.2, then gradually turning cooler (and/ or more humid?) towards the upper limit of PT19.3, as particularly suggested by a sharp decline in pollen from thermophilic plants. Atmospheric ash from renewed volcanic activity is believed to be the most likely underlying cause.

As in PT19.2, both microplankton and sporomorphs are numerically rich but only the latter are also diverse in taxa. Foraminifera and diatoms are not present.

\section{Subzone PT19.4}

The lower limit is drawn below the base of rich occurrences of Caryapollenites cf. veripites (which is immediately above the quantitative top of Labrapollis labraferoides and Interpollis spp. combined).

Note that Bombacacidites reticulatus is occasionally reworked into this subzone.

The upper limit is taken at the top of Apectodinium augustum and/or L. labraferoides; the local quantitative top of Apectodinium spp. may serve as a pointer.

Both L. labraferoides and Interpollis spp. are reduced in quantity and frequency. Inaperturopollenites hiatus and Caryapollenites spp. are generally numerically rich. Alnipollenites verus and Platycaryapollenites spp. are occasionally common, especially in upper PT19.4. The Oculopollis spp./Trudopollis spp. thermophilic morphogroup is virtually absent above the middle of the subzone. Palaeoperidinium pyrophorum becomes very rare.

Palynofacies: Restricted marine conditions with terrigenous input and widespread, abundant SOM, as seen as in PT19.3, are typical (Pl. 4, fig. 2).

The climatic trend towards relatively cool (and/or more humid?) conditions continued from upper PT19.3 into basal Eocene sequences where it is thought to reach its minimum in the ash-rich zones PT20 and PT21, suggesting a link.

Atmospheric volcanic ash, therefore, is again believed to have been the main agent for the cooling. The governing igneous activity, associated with the ongoing development of the Iceland hot spot, is known to have peaked in the Early Eocene (Knox and Morton, 1988). Future confirmation of the 

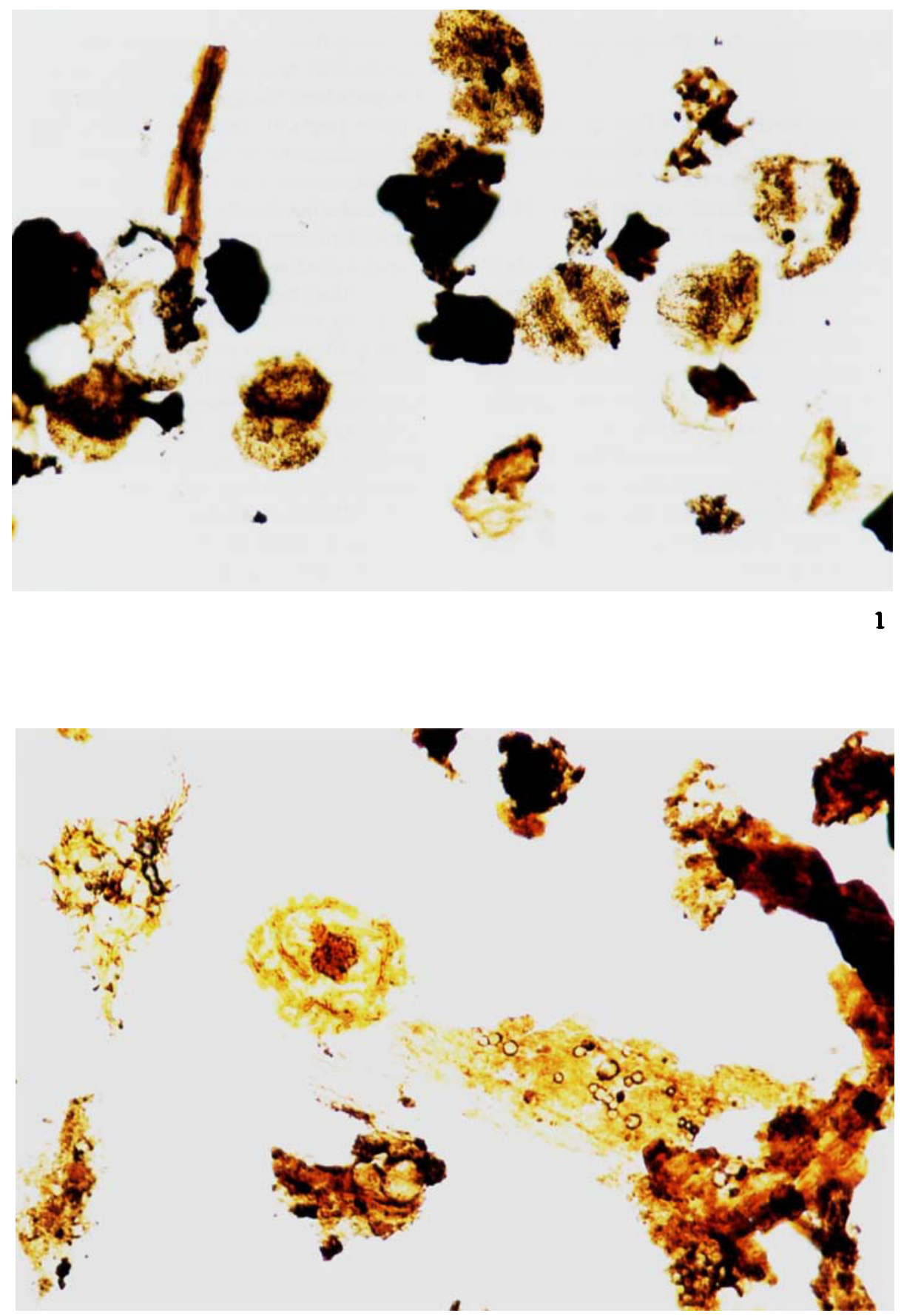

2

Explanation of Plate 3

Magnification $\times 300$, area shown approx. $420 \times 285$ microns. Coarse fraction slides (particles 30 microns and over)

Fig. 1. Palynofacies image of PT19.1.

(This facies continues into the lower part of PT19.2).

High counts of bisaccate pollen and of palynomacerals 1 and 4; well Shell/Esso 22/6-1, 7441'.

Fig 2. Palynofacies image of the upper part of PT19.2. Palynomacerals 2 and 3 are predominant over palynomacerals 1 and 4; well Sheil/Esso 22/ 6-1,7320'. 

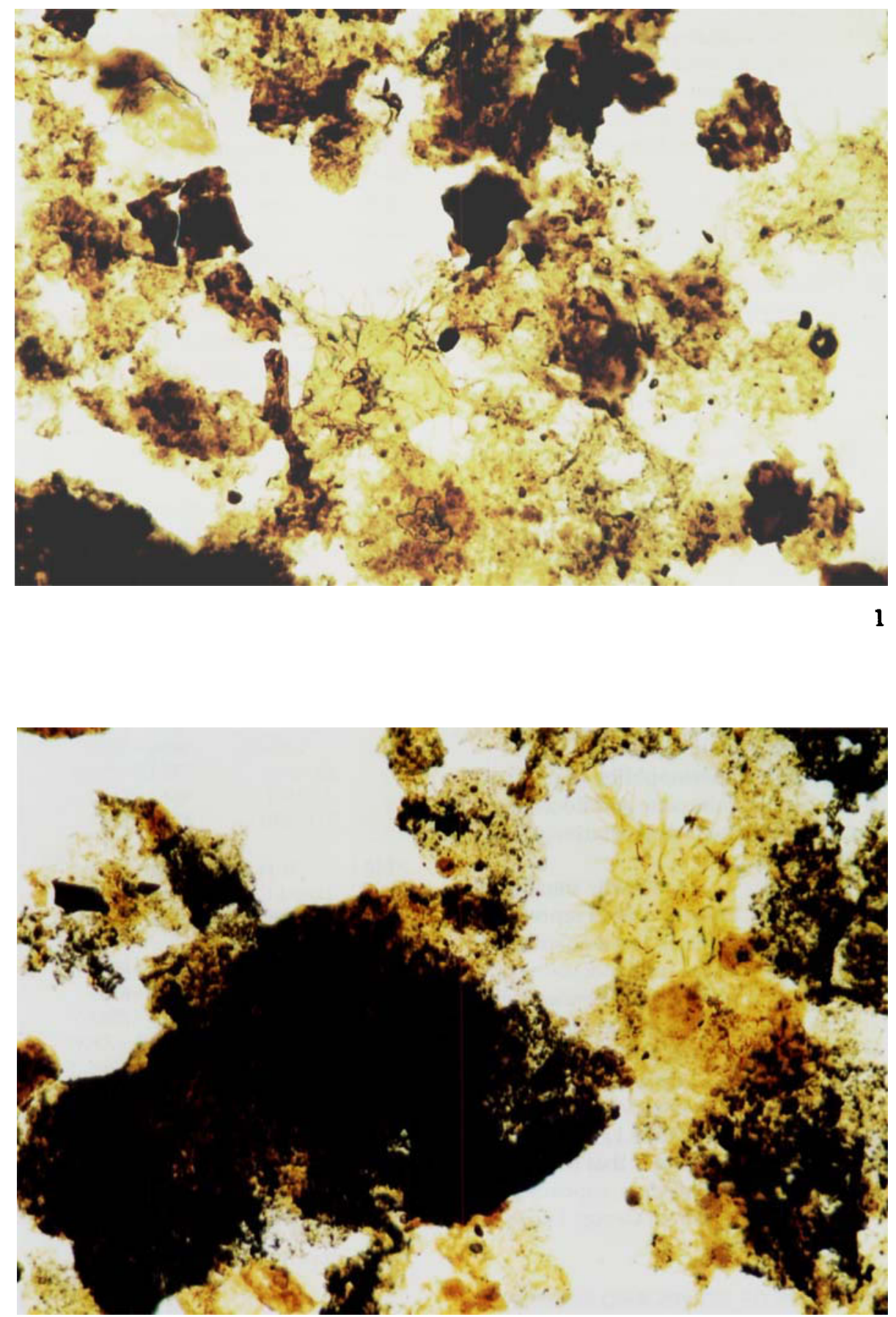

\section{Explanation of Plate 4}

Magnification $\times 300$, area shown approx. $420 \times 285$ microns. Coarse fraction slides (particles 30 microns and over)

Fig.1. Palynofacies image of PT19.3. High concentrations of degraded palynomacerals 2 and 3 typically mask palynomorphs present. SOM becomes prominent, especially in dark claystones towards the lower and upper limits of the subzone; well Shell/Esso 21/30-9A, 6534.3'.

Fig.2. Palynofacies image of PT19.4. Abundant SOM, occasionally blackened with micrinite, tends to totally mask both palynomorphs and palynomacerals 2 and 3 in claystones. (In contrast, sandstones often contain only small-sized debris of palynomaceral 1); well Arco 29/5a-3, 9518'. 
presumed presence of ash in upper PT19.3 and in PT19.4 is likely to be found in a non-turbiditic sequence.

Both microplankton and sporomorphs are rich in numbers but low in diversity. In the uppermost part of the subzone Prasinophycean algae show an upward quantitative increase, probably reflecting nutrient enrichment from the onset of a relative sea level rise.

Foraminifera and diatoms are not present although the latter reappear in the overlying zone PT20.

\section{PALAEOCLIMATIC AND EYOLUTIONARY INFLUENCES}

The composition of a parent vegetation, and that of its pollen and spores, altered radically during the climatic change of the Paleocene of Northwest Europe (Krutzsch, 1966, 1967). Massive pollen production combined with the ease and speed of dissemination ensures that changes occasioned by climate and evolution are reflected virtually simultaneously in sediments over a wide area, e.g. the palaeo-North Sea.

The climatic curve for zone PT19 (Fig. 1) is basically after Krutzsch (1967), who identified three groups of sporomorphs, the parent plants of two of which favoured a relatively warm climate and those of the third group a relatively cool one (see listing below). As the direct result of a climate change all plants of the same group were similarly affected, this determining the proportion of each group in the total vegetation.

The three groups of sporomorphs are:

1. Normapolles group: thermophilic relicts from the Late Cretaceous that favoured humid conditions.

2. Eocene-palaeotropical group: thermophiles that gradually replaced Group 1 during the Paleocene and Eocene.

3. Pre-arctoTertiary group: plants reflecting relatively cooler (and/or more humid) conditions.

Routine investigations revealed that a climatic trend comparable to that of Krutzsch (1967) appears when a representative suite of taxa from each group is taken and a quantitative plot is made. For instance, Interpollis spp. and Oculopollis spp./ Trudopollis spp. (from Group 1) combined with Bombacacidites reticulatus, Compositoipollenites rhizophorus grp. and Labrapollis labraferoides (from Group 2) are characteristic of the interval upper PT19.1 - PT19.3, whereas Alnipollenites verus, Caryapollenites veripites and Tiliaepollenites microreticulatus grp (from Group 3), combined, are typical of PT19.1/lower PT19.2 and upper PT19.3/PT19.4. Of interest here is that the quantitative distribution of Plicapollis pseudoexcelsus appears more akin to that of sporomorph Group 3 than of Group 1 as listed by Krutzsch (1967).

POSSIBLE INCOMPLETENESS OF ZONES AND SUBZONES In a complete rock sequence the quantitative increases and decreases of pollen may be gradual. In an incomplete sequence, however, sudden quantitative changes are to be expected and the nature of a submarine fan setting with several turbidites cutting into each other conforms to this picture. It also implies that differences in thickness of a particular subzone between nearby wells may reflect extra or missing section rather than proportional thickening or thinning. The same effect, however, could also be produced with switching channels and lobes and the offset stacking of sands, effectively resulting in non-deposition or condensed sequences coeval with nearby active channel depocentres (S. Goodlad, pers. comm.). It is hereby assumed that most subzones from the majority of central North Sea wells studied represent incomplete sequences.

In view of the erosive aspect of the turbidite-prone basin floor environment during PT19 times, it is impossible to establish a type section in a single well. As a consequence, the subzonal scheme is a composite from various wells.

Table 1 includes a selection of typical assemblages illustrative of the Paleocene zones and subzones from released wells.

The quoted intervals do not represent the total thickness of each zone or subzone but merely indicate the depths and intervals where core or sidewall sample coverage is available.

All listed wells are Shell/Esso ones with the exception of 29/2a-2 (Conoco) and 29/5a-3 (Arco).

For a general situation map of the North Sea, see Fig. 3.

Table 1: A selection of sample depths and intervals containing representative floras from wells in the North Sea Basin

\begin{tabular}{|c|c|c|}
\hline PT11 & $\begin{array}{l}\text { 211/29-1 : } \\
\text { 211/29-2 : }\end{array}$ & $\begin{array}{l}6262^{\prime} \\
6265^{\prime}\end{array}$ \\
\hline PT13 & $\begin{array}{l}\text { 16/8-1: } \\
30 / 19-1:\end{array}$ & $\begin{array}{l}8640^{\prime} \\
10027^{\prime}\end{array}$ \\
\hline PT15 & $\begin{array}{l}\text { 16/8-1: } \\
21 / 29 b-4: \\
22 / 6-1: \\
30 / 19-1: \\
211 / 29-1:\end{array}$ & $\begin{array}{l}7243^{\prime}-7596^{\prime} \\
5406^{\prime}-5635^{\prime} \\
7473.5^{\prime}-7683^{\prime} \\
9613^{\prime}-9633^{\prime} \\
6034^{\prime}-6073^{\prime}\end{array}$ \\
\hline PT19.1 & $\begin{array}{l}21 / 30-11: \\
22 / 6-1: \\
22 / 6 a-8:\end{array}$ & $\begin{array}{l}6186^{\prime}-6376^{\prime} \\
7361.5^{\prime}-7463^{\prime} \\
7344^{\prime}-7472^{\prime}\end{array}$ \\
\hline PT19.2 & $\begin{array}{l}21 / 30-9 A: \\
21 / 30-11: \\
22 / 6-1: \\
22 / 6 a-8:\end{array}$ & $\begin{array}{l}6639^{\prime}-6684^{\prime} \\
6070^{\prime}-6137^{\prime} \\
7320^{\prime}-7343.5^{\prime} \\
7281.7^{\prime}-7319^{\prime}\end{array}$ \\
\hline PT19.3 & $\begin{array}{l}16 / 8-1: \\
21 / 30-6: \\
21 / 30-8: \\
21 / 30-9 A: \\
22 / 6-1: \\
22 / 6 a-8: \\
29 / 2 a-2: \\
29 / 3-1:\end{array}$ & $\begin{array}{l}6994^{\prime}-7089^{\prime} \\
6683^{\prime}-6932^{\prime} \\
6074^{\prime}-6224^{\prime} \\
6426^{\prime}-6638^{\prime} \\
7219^{\prime}-7299.5^{\prime} \\
7229^{\prime}-7266.5^{\prime} \\
8781^{\prime}-8817^{\prime} \\
8665^{\prime}-8752^{\prime}\end{array}$ \\
\hline PT19.4 & $\begin{array}{l}16 / 8-1: \\
22 / 6-1: \\
29 / 2 a-2: \\
29 / 3-1: \\
29 / 5 a-3: \\
30 / 19-1: \\
211 / 29-1:\end{array}$ & $\begin{array}{l}6982^{\prime} \\
7180^{\prime}-7198^{\prime} \\
8740^{\prime}-8748^{\prime} \\
8599^{\prime}-8637.5^{\prime} \\
9518^{\prime}-95755^{\prime} \\
9450^{\prime}-9515^{\prime} \\
5660^{\prime}\end{array}$ \\
\hline
\end{tabular}




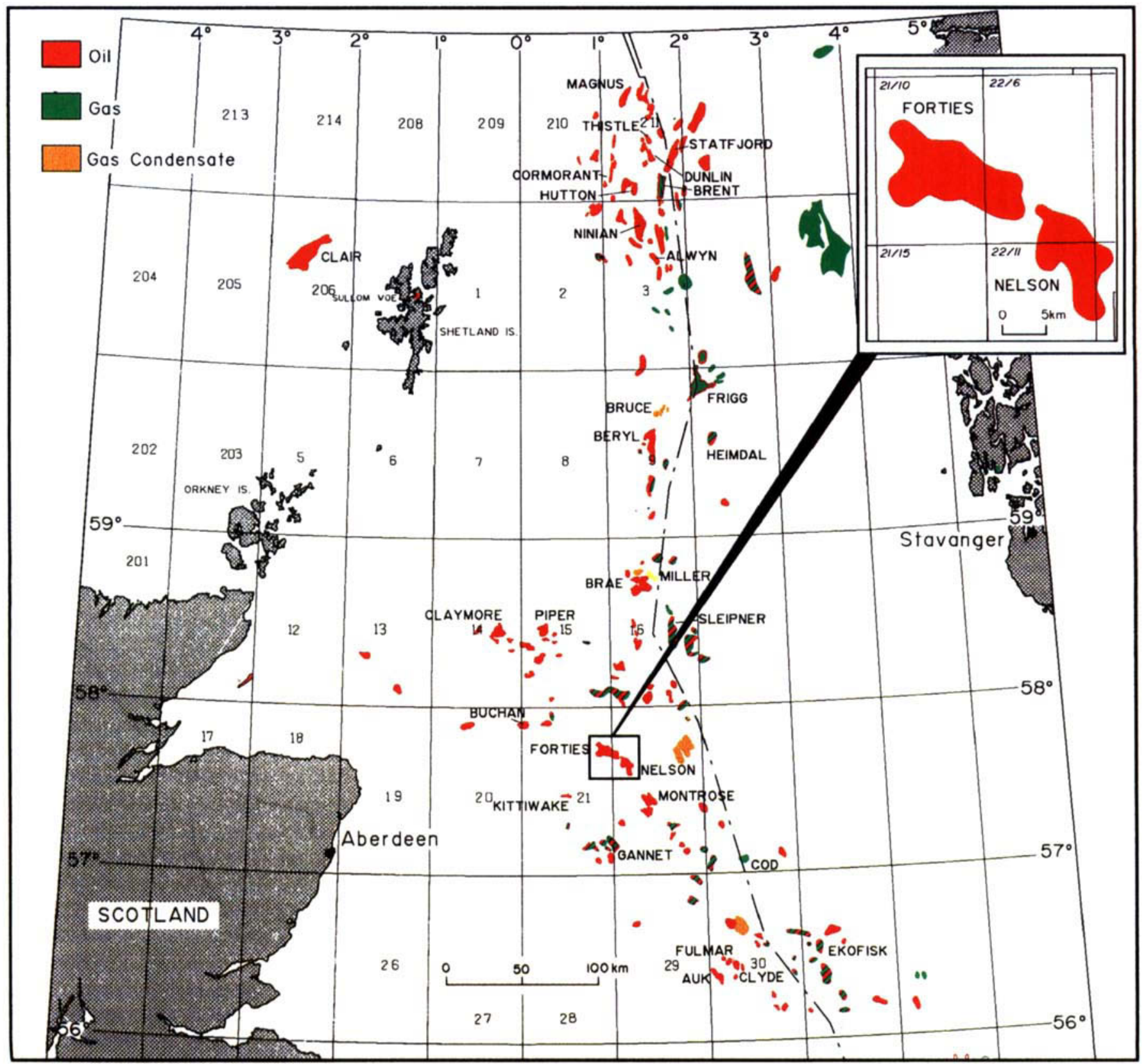

Fig. 3. North Sea Situation Map (insert is the Forties area)

\section{GEOGRAPHIC VALIDITY AND APPLICATION OF THE PT ZONATION}

In the early days of offshore North Sea exploration, before oil discoveries had been made in the Paleocene, recognition of the four main zones - PT11, PT13, PT15 and PT19 - sufficed as a means of routine biostratigraphic control. Well over twenty years later their presence is known to be widespread in the North Sea and records are also known from the West Shetland Basin.

However, once the Lower Tertiary of the central North Sea had turned into a hydrocarbon play, a higher biostratigraphic resolution was required in order to unravel the intricate distribution of sand bodies. The subzones of PT19 met these requirements and proved important as a chronostratigraphic framework for geological modelling and for defining the various reservoir units within the Forties Formation of the Gannet B, Gannet C and Guillemot Fields (Armstrong et al., 1987) and of the Forties Field (Kulpecz \& Van Geuns, 1990). The current emphasis lies on the development of the Nelson field, where fourteen wells have so far been palynologically studied and the consistency of the subzonal scheme is apparent. The geological cross section between the southeast por- 


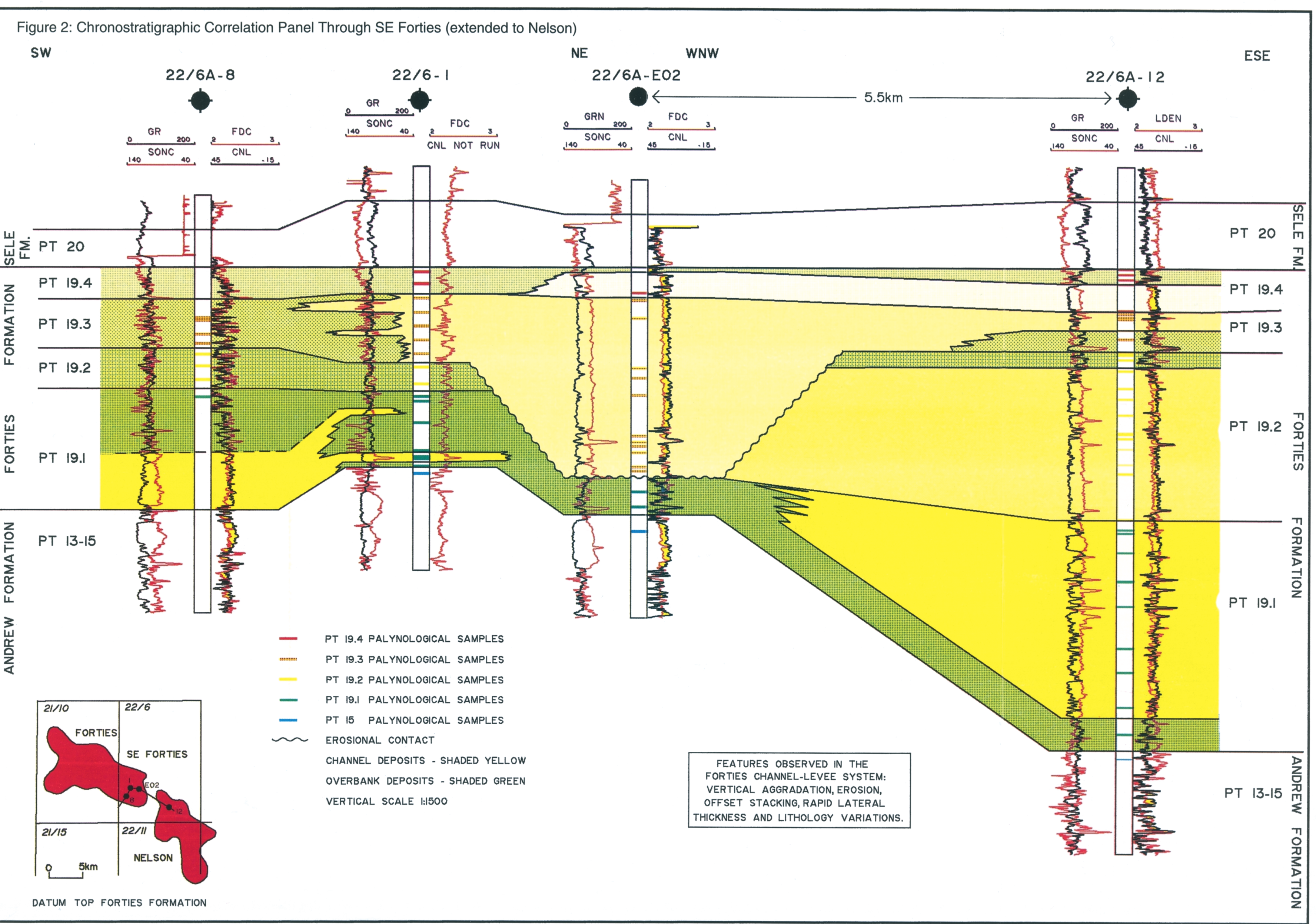




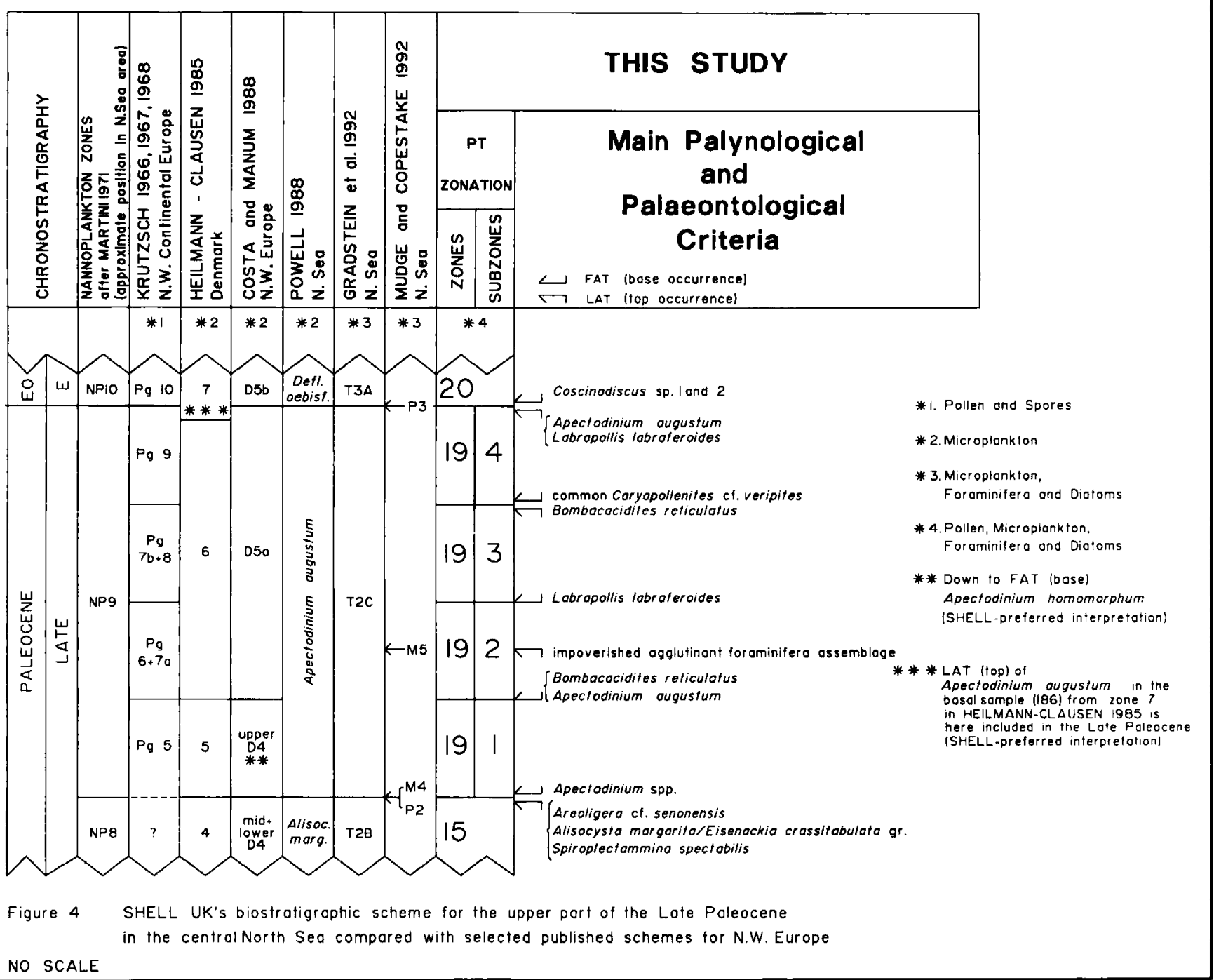

Fig. 4. SHELL UK's biostratigraphic scheme for the upper part of the Late Paleocene in the central North Sea compared with selected published schemes for N.W. Europe.

tion of the Forties Field and the Nelson well Shell/Esso 22/ 6a-12 (Fig. 2) clearly demonstrates that the scheme is instrumental in establishing correlations within the Forties Formation. Offset stacking of the subsequent channels as a result of channel switching is shown in this figure. The palynological subdivision indicates the rapid transition from the thick PT19.3 age channel sands in well 22/6a-E02 to much thinner overbank silts and shales in well 22/6-1. The absence of a PT19.2 section in well $22 / 6 a-E 02$ suggests a strong erosional component in the early stages of the overlying PT19.3 channel. Well 22/ 6a-12 from the Nelson field is included to extend the lateral dimension of the section and show the relationship of channels of different ages.

The geographical limits of application of the PT19 subzonal scheme outside the central North Sea, South Viking Graben, Outer Moray Firth and Central Graben, are still uncertain. Since it served as a model for the pollen scheme of Shell's zonation, it is already known that basic compatibility exists with the zonation of Krutzsch $(1966,1967,1968,1970)$ for central and northern Germany. On the other hand, first indications from the WestShetland Basin are that the Late Paleocene pollen floras differ in composition and that the 'North Sea' scheme cannot be applied in detail.

\section{COMPARISON WITH SELECTED PUBLISHED DATA}

A tentative comparison between Shell U.K.'s palynozonation and already published schemes is shown in Fig. 4. Included in that comparison are foraminiferal events that form an integral part of biostratigraphic control in the Paleocene. Since the zonation by Krutzsch is central to Shell's scheme, particular reference is made here to a direct correlation between the two, afforded by the ranges of two species restricted to a part of the Late Paleocene: 


\section{Labrapollis labraferoides}

(Krutzsch 1968: Pg 7b - ?Pg 9 = Shell U.K. PT19.3 - PT19.4)

Note: ?Pg 9 is here interpreted to indicate a possible upwards extension into basal Pg 10 (Krutzsch 1966, 1970). An earlier, isolated, reported presence in zone Pg 5 (Krutzsch 1966, 1970) omitted in Krutzsch 1968, has been ignored since $L$. labraferoides has never been observed below the base of Bombacacidites reticulatus in North Sea wells.

\section{Bombacacidites reticulatus}

(Krutzsch 1966: Pg 6 - Pg 8 = Shell U.K. PT19.2 - PT19.3)

\section{CONCLUSIONS}

Shell U.K.'s palynological scheme for the Paleocene is purely operational containing only selected species with proven marker value. Identification of pollen marker taxa was based initially on literature and supplemented with microplankton ranges established in-house.

The ranges of the nine main marker taxa that define the zonal and subzonal PT boundaries have remained virtually unchanged over the years. The stratigraphic and quantitative distribution of ten additional taxa used for 'fine tuning' have slightly changed, and may continue to do so, as the result of an ever growing database.

The four main PT zones are widespread in the North Sea and West Shetland Basin. The largely pollen-based subdivision of the youngest PT19 zone is essentially a geographic extension of a broadly similar scheme for North West continental Europe. The main area of application of the PT19 subzonal scheme is the central North Sea where it has been tested for over twenty years. Because of the limited geographical extent of the central North Sea as a catchment basin for pollen from roughly the same vegetational belt, the subzones are most probably isochronous. This is especially the case when evolutionary and palaeoclimatic changes are accepted as the overriding factors dictating the floral composition of the vegetational belt over a much wider area.

The erosive aspect of a Paleocene environment of deposition, containing turbidite systems, may mean that sudden jumps in the quantitative pollen distribution are a reflection of missing section. Rapid lateral differences in thickness of a floral subzone over short distances suggest an incomplete sequence. A much finer resolution than available to date may well be required to test this assumption fully but, if correct, the possibilities for improved intra-field evaluation are obvious.

\section{ACKNOWLEDGEMENTS}

The author is indebted to Shell Internationale Petroleum Maatschappij, Shell U.K. Exploration and Production and to Esso U.K. Exploration and Production for their permission and support to publish this paper. Thanks are also due to colleagues in both the Exploration and Production Departments of Shell U.K. for their suggestions, contributions and assistance. The British Micropalaeontological Society acknowledges the financial support of Shell UK Exploration and Production for the publication of this paper.

\section{Manuscript received June 1992}

Manuscript accepted October 1992

\section{REFERENCES}

Armstrong, L.A., Ten Have, A. and Johnson, H.D. 1987. The geology of the Gannet Fields, central North Sea, UK sector. In Brooks, J. and Glennie, K. (eds.), Petroleum Geology of North West Europe, 533-548. Graham \& Trotman, London.

Costa, L. I. and Manum, S.B. 1988. The description of the interregional zonation of the Paleogene (D1-D15) and the Miocene(D16-D20). In Vinken, R. (comp.). The Northwest European Tertiary Basin. Results of the International Geological Correlation Programme Project 124. Dinoflagellates, compiled by MEYER, K-J.; Geol. Jb., 100, 321-330, Hanover.

Gradstein, F.M., Kristiansen, I.L., Loemo, L. and Kaminsky, M.A. 1992. Cenozoic foraminiferal and dinoflagellate cyst biostratigraphy of the central North Sea.

Micropaleontology, 38, 101-137, New York.

Harland, W.B., Armstrong, R.L., Cox, A.V., Craig, L.E., Smith, A.G. and Smith, D.G. 1990. A geologic time scale 1989. xvi + 263 pp., Cambridge University Press.

Heilmann-Clausen, C. 1985. Dinoflagellate stratigraphy of the uppermost Danian to Ypresian in the Viborg 1 borehole, central Jylland, Denmark. Dansk. Geol. Unders_gelse Ser. A, 7, 1-69, Copenhagen.

Knox, R.W. O'B. and Morton, A.C. 1988. The record of early Tertiary $\mathrm{N}$. Atlantic volcanism in sediments of the North Sea Basin. In Morton, A.C. and Parson, L.M. (eds.) Early Tertiary Volcanism and the Opening of the NE Atlantic. Geological Society Special Publication, 39, 407-419, Oxford.

Krutzsch, W. 1962. Stratigraphisch bzw. botanisch wichtige neue Sporen - und Pollenformen aus dem deutschen Tertiär. Geologie, 11, 265-308, Berlin.

Krutzsch, W. 1966. DiesporenstratigraphischeGliederung desälteren Tertiär im nördlichen Mitteleuropa (Paläozän - Mitteloligozän) methodische Grundlagen und gegenwärtiger Stand der Untersuchungen. Abh. zentr. geol. Inst., 8, 112-149, Berlin.

Krutzsch, W. 1967. Der Florenwechsel im Alttertiär Mitteleuropas auf Grund von sporenpaläontologischen Untersuchungen. In Klimaänderungen im Tertiär aus paläobotanischer Sicht. Abh. zentr. geol. Inst., 10, 17-37, Berlin.

Krutzsch,W. 1968. Brosipollis und Labrapollis, zwei neue Pollengenera aus dem Tertiär Mitteleuropas. Review Palaeobotan. Palynol., 6, 61-70, Amsterdam.

Krutzsch, W. 1970. Die stratigraphisch verwertbaren Sporen - und Pollenformen des mitteleuropäischen Alttertiärs. Jb. f. Geol., 3, 309-379, Berlin.

Kulpecz, A.A. and Geuns, L.C. van 1990. Geological modeling of a turbidite reservoir, Forties Field, NorthSea.. In Barwis/McPherson/ Studlick, (eds.), Casebooks in Earth Science, Sandstone Petroleum Reservoirs, (Springer-Verlag Inc.), 489-507, New York,

Lentin, J.K. and Williams, G.L. 1989. Fossil dinoflagellates: index to genera and species.

AASP, Contributions Series, 20, 1-473, Dallas.

Martini, E. 1971. Standard Tertiary and Quaternary calcareous nannoplankton zonation. In: Proceedings of the II Planktonic Conference Roma, 1969, 739-785. Edizioni Tecnoscienza, Rome.

Mudge, D.C. and Copestake, P. 1992. Revised Lower Palaeogene lithostratigraphy for the Outer Moray Firth, North Sea. Marine Petrol. Geol., 9, 53-69, Guildford.

Nichols, D.J. and Ott, H.L. 1978. Biostratigraphy and evolution of the Momipites-Caryapollenites lineage in the Early Tertiary in the Wind River Basin, Wyoming.

Palynology, 2, 93-112, Dallas.

Powell, A.J. 1988. A modified dinoflagellate cyst biozonation for latest Palaeocene and earliest Eocene sediments from the central North Sea. Rev. Palaeobot. Palynol., 56, 327-344, Amsterdam.

Van der Zwan, C.J. 1990. Palynostratigraphy and palynofacies reconstruction of the Upper Jurassic to lowermost Cretaceous of the Draugen Field, offshore Mid Norway. Rev. Palaeobot. Palynol., 62, 157-186, Amsterdam. 
Whitaker, M.F. 1984. The usage of palynostratigraphy and palynofacies in definition of Troll Field geology. In Offshore Northern Seas Reduction of Uncertainties by Innovative Reservoir Geomodelling. Norsk Petroleumsforening, Article G6.

Ziegler, P.A. 1990. Geological Atlas of Western and Central Europe. 2nd ed. Geol. Soc. Publ., Bath, 239p. and 56 plates. 